\title{
Comparative Analysis of Health Institutions, Personnel and Service in Private and Public Health Sector in Serbia in 2009
}

\author{
Milena Gajić-Stevanović1, Snežana Dimitrijević1, Nevenka Teodorović2, Slavoljub Živković2 \\ "Institute of Public Health of Serbia "Dr. Milan Jovanović Batut", Belgrade, Serbia; \\ ${ }^{2} \mathrm{~S}$ chool of Dentistry, University of Belgrade, Belgrade, Serbia
}

\begin{abstract}
SUMMARY
Introduction Collecting data about the structure and function of private health care sector in Serbia and its inclusion in joint health care system is one of the most important issues for making decisions in health care and getting more accurate picture about the possibilities of health care system in Serbia. The aim of this analysis was to compare health institutions, personnel, visits, number of hospital days and morbidity by ICD-10 classification of diseases in public and private health sector in South Backa, Nisava, Toplica and Belgrade district in 2009.

Material and Methods A retrospective comparative analysis was performed using data about private providers of health services obtained from the Institute of Public Health Novi Sad, the Institute of Public Health Nis and the City Institute of Public Health Belgrade. Data about personnel and morbidity in public health sector in Serbia for 2009 was obtained from the Center for Information Technology of the Institute for Public Health of Serbia. Data about public health facilities in South Backa, Nisava, Toplica and Belgrade district in 2009 was obtained from Serbian Chamber of medical institutions.

Results The results showed that health care was provided in Belgrade district in 2009 by total of 1,051 employees in private sector and 31,404 in public sector. We found that public sector had a far wider range of health facilities than private sector, which was mainly due to the number of clinics. In South Backa district private sector had 323 practices, the district of Belgrade 655 and Nisava and Toplica district 173. Seventeen times more visits to households $(4,650,423$ vs. 267,356) and 111 times greater number of hospital days was provided in public health sector as compared to private health sector $(781,083$ vs. 7,023$)$ in South Backa district.

Conclusion The conclusion of this analysis was that public health sector has remained the foundation of health care system in Serbia. Private health sector is expanding, but its structure and scope of services is still undervalued as compared to public sector.
\end{abstract}

Keywords: private health care sector; health care; public health care sector in Serbia

\section{INTRODUCTION}

Health Care Law (Law of Health Care Sluzbeni glasnik No. 107/05) in Article 45. states that health care service includes health care facilities and private practices, as well as health workers and associates who provide health care in health institutions and private practices. Health facilities may be established as public or private property, and founders may be, in addition to various state bodies, lawful as well as ordinary people. Private practice may be established by unemployed health worker who has passed board exam or retired health care worker, if he/she obtains an agreement from the Chamber of health workers. To establish and run health institutions, different rules apply for private and public ownerships. Health care facilities owned by the state are established in accordance to the network of health institutions, and the founders are, depending on the type of institution, republic, autonomous province, city or municipality. Given that they are set upped as institutions that operate activities of public interest, their establishment and management bodies are defined by the Civil Service Law [1]. On the other hand, private health care providers in most cases operate as private practices; they are established and operate in accordance with the Law of Private Entrepreneurs [2].

There are number of companies, mainly in the form of limited liability companies that operate in accordance with the Law of Private Companies [3]. A precise overview of the number of entrepreneurs and companies that provide health care services is not available from public sources, since the Republic Statistical Office (RSO) in communications related to the statistical registers publishes cumulative data related to the activity of "Health and social work", and the extraction of health care service providers only, requires additional disaggregation of data. As with all other business entities, two statistics have been keeping, one that relates to companies, institutions, cooperatives and other organizations and the other that relates to entrepreneurs and their employees. This method of data collection is often accompanied by inadequate presentation of certain statistic indicators.

Private health care providers have limitations for health care services that they can provide. In fact, there are several activities listed in Articles 48. and 56. of Health Care 
Act [4] that can be performed exclusively in public health care facilities.

The structure of private health sector is various, and distribution of health facilities is territorially dispersed. However, data about the type of services provided by private health institutions is missing despite obligation for record-keeping and data sharing between health care providers and relevant government departments and institutes which should aggregate all data about health sector.

The aim of this analysis was to compare health facilities, personnel, visits, number of patient days (hospital days) and morbidity by ICD-10 classification of diseases in public and private sectors in South Backa, Nisava and Toplica, and Belgrade district in 2009.

\section{MATERIAL AND METHODS}

Data about private health service providers was obtained from the Institute of Public Health Novi Sad, the Institute of Public Health Nis and the City Institute of Public Health Belgrade. Data about staff and morbidity in public health sector in Serbia for 2009 was obtained from the Center for Informatics of the Institute of Public Health, Serbia. Network of public health institutions in South Backa, Nisava and Toplica, and Belgrade district in 2009 was obtained from Serbian chamber of health institutions.

\section{RESULTS}

Based on available data, the number of private health institutions in Serbia in 2009 was 5,519 (Table 1) and the number of public health institutions was 366 (Table 2).

Based on Table 3, a total number of 439 medical clinics/institutions were included in private health sector in South Backa district. Of these, most were dental practices

Table 1. Private health institutions in Serbia in 2009

Tabela 1. Privatne ustanove u Srbiji 2009. godine

\begin{tabular}{|l|c|}
\hline $\begin{array}{l}\text { Private health institutions } \\
\text { Privatne zdravstvene ustanove }\end{array}$ & $\begin{array}{c}\text { Number } \\
\text { Broj }\end{array}$ \\
\hline $\begin{array}{l}\text { Health center and polyclinic } \\
\text { Dom zdravlja i poliklinika }\end{array}$ & 152 \\
\hline $\begin{array}{l}\text { Hospital } \\
\text { Bolnica }\end{array}$ & 72 \\
\hline $\begin{array}{l}\text { General practice } \\
\text { Ordinacija opšte prakse }\end{array}$ & 1,047 \\
\hline $\begin{array}{l}\text { Dental practice } \\
\text { Stomatološka ordinacija }\end{array}$ & 1,989 \\
\hline $\begin{array}{l}\text { Other health practice } \\
\text { Ordinacija drugih zdravstvenih radnika }\end{array}$ & 112 \\
\hline $\begin{array}{l}\text { Home care } \\
\text { Kućna nega }\end{array}$ & 30 \\
\hline $\begin{array}{l}\text { Medical laboratories } \\
\text { Medicinske laboratorije }\end{array}$ & 337 \\
\hline $\begin{array}{l}\text { Pharmacies } \\
\text { Apotekarska ustanova }\end{array}$ & 1,457 \\
\hline $\begin{array}{l}\text { Total } \\
\text { Ukupno }\end{array}$ & $\mathbf{5 , 5 1 9}$ \\
\hline
\end{tabular}

Source: The Institute for Public Health of Serbia, 2010 Izvor: Institut za javno zdravlje Srbije, 2010. godina
Table 2. Public health institutions in Serbia in 2009

Tabela 2. Državne zdravstvene ustanove u Srbiji 2009. godine

\begin{tabular}{|l|c|}
\hline $\begin{array}{l}\text { Public health institutions } \\
\text { Državne zdravstvene ustanove }\end{array}$ & $\begin{array}{c}\text { Number } \\
\text { Broj }\end{array}$ \\
\hline $\begin{array}{l}\text { Health center } \\
\text { Dom zdravlja }\end{array}$ & 157 \\
\hline $\begin{array}{l}\text { Clinic center } \\
\text { Klinički centar }\end{array}$ & 4 \\
\hline $\begin{array}{l}\text { Clinic-hospital center } \\
\text { Kliničko-bolnički centar }\end{array}$ & 4 \\
\hline $\begin{array}{l}\text { Health center } \\
\text { Zdravstveni centar }\end{array}$ & 21 \\
\hline $\begin{array}{l}\text { General hospital } \\
\text { Opšta bolnica }\end{array}$ & 40 \\
\hline $\begin{array}{l}\text { Special hospital } \\
\text { Specijalna bolnica }\end{array}$ & 37 \\
\hline $\begin{array}{l}\text { Clinic } \\
\text { Klinika }\end{array}$ & 6 \\
\hline $\begin{array}{l}\text { Department } \\
\text { Zavod }\end{array}$ & 22 \\
\hline $\begin{array}{l}\text { Institute } \\
\text { Institut }\end{array}$ & 366 \\
\hline $\begin{array}{l}\text { Institute/department for public health } \\
\text { Institut/zavod za javno zdravlje }\end{array}$ & 23 \\
\hline $\begin{array}{l}\text { Pharmacies } \\
\text { Apotekarska ustanova }\end{array}$ & 36 \\
\hline $\begin{array}{l}\text { Total } \\
\text { Ukupno }\end{array}$ & 23 \\
\hline
\end{tabular}

Source: The Institute for Public Health of Serbia, 2010

Izvor: Institut za javno zdravlje Srbije, 2010. godina

(222), general medical and specialized practices (83) and pharmacies (63).

Different structure and organization of institutions in public health sector was the reason for significantly lower total number of institutions in public than in private sector (Table 4).

South Backa District had strong network of public health institutions, including one clinic center. These institutions provided health care to the entire population on its territory. Data about the number of employees presented in Table 5 revealed that public health sector had 7.5 times more employees than private health sector in South Backa District, as follows: three times was greater number of employed doctors and pharmacists, and about 8 times more employees with higher and secondary education were recorded in public versus private health sector.

Underdevelopment of private health sector was obvious when compared to public sector e.g. public health sector provided 17 times more visits to households $(4,650,423$ vs. 267,356$)$ and achieved 111 times more hospital days as compared to private health sector $(781,083$ vs. 7,023$)$.

The assessment of private health sector conducted by the Institute for Economic and Social Research in March 2009 confirmed that private sector was still poorly present in the delivery of health services to the population. In regards to the services used by sectors, the population most frequently used dental services in private sector, while outpatient treatment services in outpatient clinics were used by $1.2 \%$ of the population only (in total population there were $27.2 \%$ of users), as well as hospital treatment was used by only $0.1 \%$ of the population $(6.1 \%$ of total population used hospital services at all). 
Table 3. Health institutions in private sector in South Backa district in 2009

Tabela 3. Privatne zdravstvene ustanove u Južnobačkom okrugu 2009. godine

\begin{tabular}{|l|c|}
\hline $\begin{array}{l}\text { Private health institutions } \\
\text { Privatne zdravstvene ustanove }\end{array}$ & $\begin{array}{c}\text { Number } \\
\text { Broj }\end{array}$ \\
\hline $\begin{array}{l}\text { General and specialized practice } \\
\text { Opšta i specijalistička ordinacija }\end{array}$ & 83 \\
\hline $\begin{array}{l}\text { Practise for gynecology and obstetrics } \\
\text { Ginekološko-akušerska ordinacija }\end{array}$ & 18 \\
\hline $\begin{array}{l}\text { Dental practice } \\
\text { Stomatološka ordinacija }\end{array}$ & 222 \\
\hline $\begin{array}{l}\text { Health center } \\
\text { Dom zdravlja }\end{array}$ & - \\
\hline $\begin{array}{l}\text { Polyclinic } \\
\text { Poliklinika }\end{array}$ & 11 \\
\hline $\begin{array}{l}\text { Medical office } \\
\text { Ambulanta }\end{array}$ & 2 \\
\hline $\begin{array}{l}\text { Hospital } \\
\text { Bolnica }\end{array}$ & 7 \\
\hline $\begin{array}{l}\text { Laboratory } \\
\text { Laboratorija }\end{array}$ & 13 \\
\hline $\begin{array}{l}\text { Laboratory for dental technics } \\
\text { Laboratorija za zubnu tehniku }\end{array}$ & 4 \\
\hline $\begin{array}{l}\text { Pharmacies } \\
\text { Apoteka }\end{array}$ & 63 \\
\hline $\begin{array}{l}\text { Department } \\
\text { Zavod }\end{array}$ & $\mathbf{4 3 9}$ \\
\hline $\begin{array}{l}\text { Rehabilitation center } \\
\text { Rehabilitacioni centar }\end{array}$ & - \\
\hline $\begin{array}{l}\text { Total } \\
\text { Ukupno }\end{array}$ & \\
\hline Soure:The Intiote for Publitelthof & \\
\hline
\end{tabular}

Source: The Institute for Public Health of Vojvodina, 2010

Izvor: Institut za javno zdravlje Vojvodine, 2010. godina

The data showed that dental services were equally used in public and private sectors which was the result of legislative adjustment on use of this service, and ways of providing dental services in public health centers.

The analysis of morbidity pictures, both in private and public health sector by ICD-10 classification of diseases is shown in Tables 6, 7 and 8.

The analysis of school children health care indicated that private health sector was mostly used by patients suffering from diseases of respiratory system (34\%), uro-genital system (10\%), infectious and parasitic diseases (9\%), while public health sector was mostly used by patients suffering from respiratory system (45\%), infectious and parasitic diseases (14\%). Total number of patients in the health care of school children in private sector was 91, while in public sector it was 197,713.

On the morbidity list by ICD-10, practices for gynecological and obstetric diseases in private health sector were visited mostly by those who suffered from diseases of uro-
Table 4. Health institutions in public sector in South Backa district in 2009.

Tabela 4. Državne zdravstvene ustanove u Južnobačkom okrugu 2009 godine

\begin{tabular}{|l|c|}
\hline $\begin{array}{l}\text { Public health institutions } \\
\text { Državne zdravstvene ustanove }\end{array}$ & $\begin{array}{c}\text { Number } \\
\text { Broj }\end{array}$ \\
\hline $\begin{array}{l}\text { Health center } \\
\text { Dom zdravlja }\end{array}$ & 11 \\
\hline $\begin{array}{l}\text { Clinic center } \\
\text { Klinički centar }\end{array}$ & 1 \\
\hline $\begin{array}{l}\text { General hospital } \\
\text { Opšta bolnica }\end{array}$ & 1 \\
\hline $\begin{array}{l}\text { Special hospital } \\
\text { Specijalna bolnica }\end{array}$ & 1 \\
\hline $\begin{array}{l}\text { Clinic } \\
\text { Klinika }\end{array}$ & 1 \\
\hline $\begin{array}{l}\text { Department } \\
\text { Zavod }\end{array}$ & 5 \\
\hline $\begin{array}{l}\text { Institute } \\
\text { Institut }\end{array}$ & 4 \\
\hline $\begin{array}{l}\text { Institute/department for public health } \\
\text { Institut/zavod za javno zdravlje }\end{array}$ & 1 \\
\hline $\begin{array}{l}\text { Pharmacies } \\
\text { Apotekarska ustanova }\end{array}$ & 27 \\
\hline $\begin{array}{l}\text { Total } \\
\text { Ukupno }\end{array}$ & $\mathbf{2 7}$ \\
\hline
\end{tabular}

Source: Serbian Chamber of Health Institutions, 2010 Izvor: Komora zdravstvenih ustanova Srbije, 2010. godina

genital system (54\%) and tumors (13\%), while public health sector provided health care to those who suffered from diseases of uro-genital system (45\%) and diseases that affected their health status and contact with health service (43\%). The total number of patients in private practices for gynecology and obstetrics amounted 401, while in public sector it was 68,108 .

The practices for dermato-venereal diseases in private health sector were mostly visited by those who suffered of infectious and parasitic diseases (47.5\%) and tumors (25\%), while public health sector was mostly used by those who suffered from dermatological diseases and diseases of subcutaneous tissue $(63 \%)$, infectious and parasitic diseases (19\%). The total number of patients in dermatovenereal practices in private health sector was 40 , while in public sector was 26,590 .

Analysis of dental service (morbidity for adults) showed that private health sector was mostly visited by patients who suffered from diseases of digestive system (100\%). Similarly, in public sector, dental service was used mostly by the same type of patients (97\%). The total number of patients in dental practice (morbidity in adults) in private sector amounted 406 , while in public sector it was 210,057.

Table 5. Number of employees in private and public sector in South Backa district in 2009

Tabela 5. Broj zaposlenih u privatnom i državnom sektoru u Južnobačkom okrugu 2009. godine

\begin{tabular}{|l|c|c|c|c|c|c|}
\hline $\begin{array}{l}\text { Sector } \\
\text { Sektor }\end{array}$ & $\begin{array}{c}\text { Total employees } \\
\text { Ukupno zaposlenih }\end{array}$ & $\begin{array}{c}\text { Doctors } \\
\text { Lekari }\end{array}$ & $\begin{array}{c}\text { Pharmacists } \\
\text { Farmaceuti }\end{array}$ & $\begin{array}{c}\text { Nurses and technicians } \\
\text { Sestre i tehničari }\end{array}$ & $\begin{array}{c}\text { Visits } \\
\text { Posete lekaru }\end{array}$ & $\begin{array}{c}\text { Hospital days } \\
\text { Bolnički dani }\end{array}$ \\
\hline $\begin{array}{l}\text { Private } \\
\text { Privatni }\end{array}$ & 1,347 & 703 & - & 644 & 267,356 & 7,023 \\
\hline $\begin{array}{l}\text { Public } \\
\text { Državni }\end{array}$ & 10,185 & 1,925 & 139 & 4,981 & $4,650,423$ & 781,083 \\
\hline
\end{tabular}

Source: The Institute for Public Health of Vojvodina, 2010, and The Institute for Public Health of Serbia, 2010

Izvor: Institut za javno zdravlje Vojvodine, 2010, i Institut za javno zdravlje Srbije, 2010. 


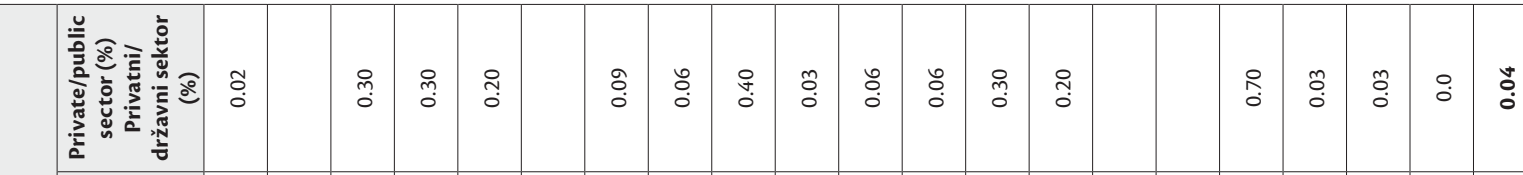

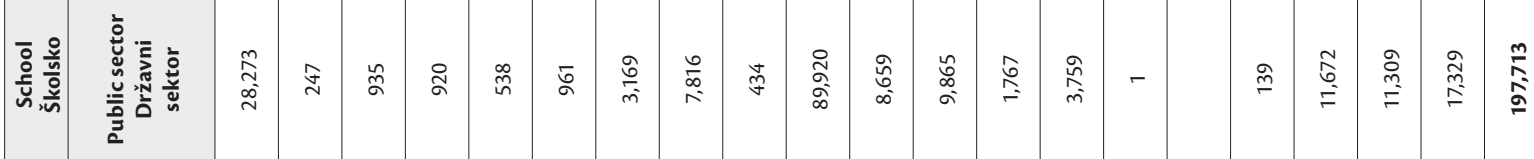

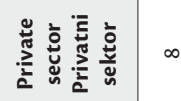

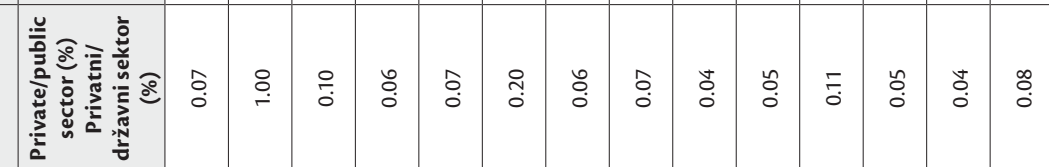

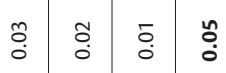

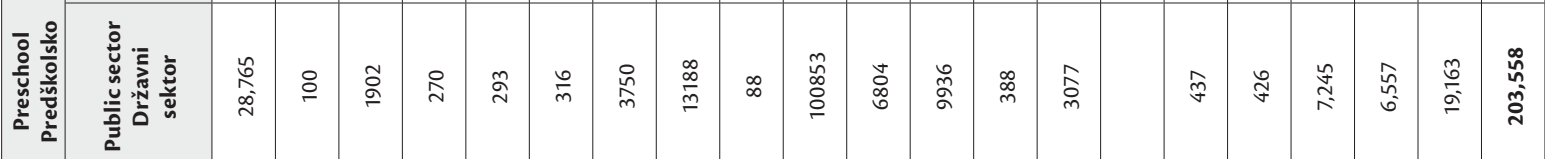

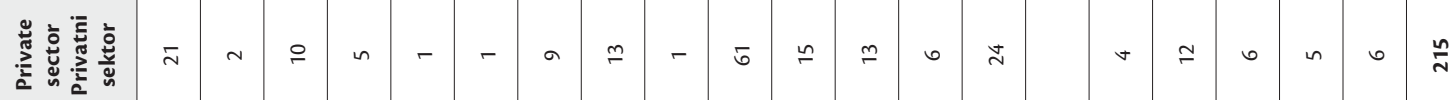

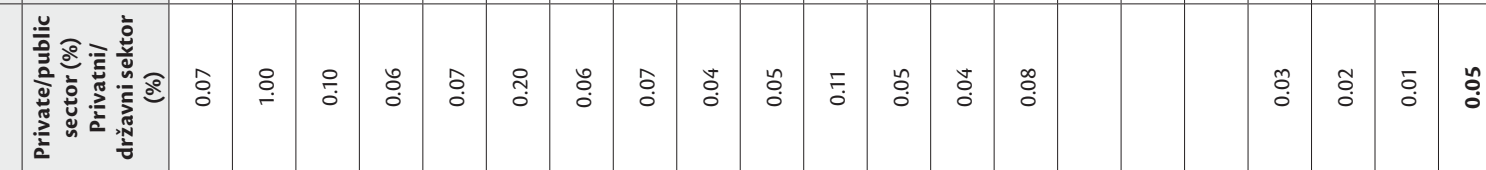

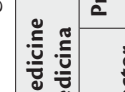

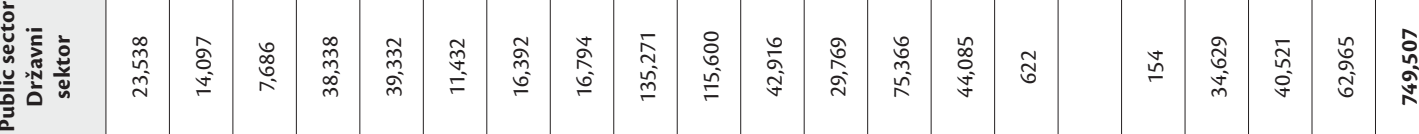

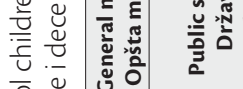

它豙

㐾

을

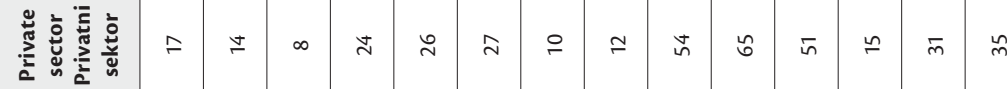

흘 흔

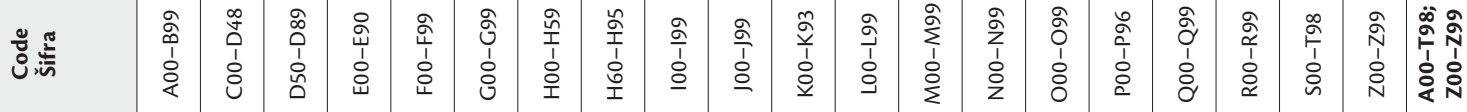

䓪.

䒕

岳 离

竞:

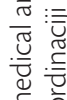

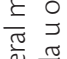

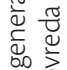

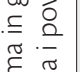

宽

동

凹ั $\frac{\bar{\omega}}{\overline{0}}$

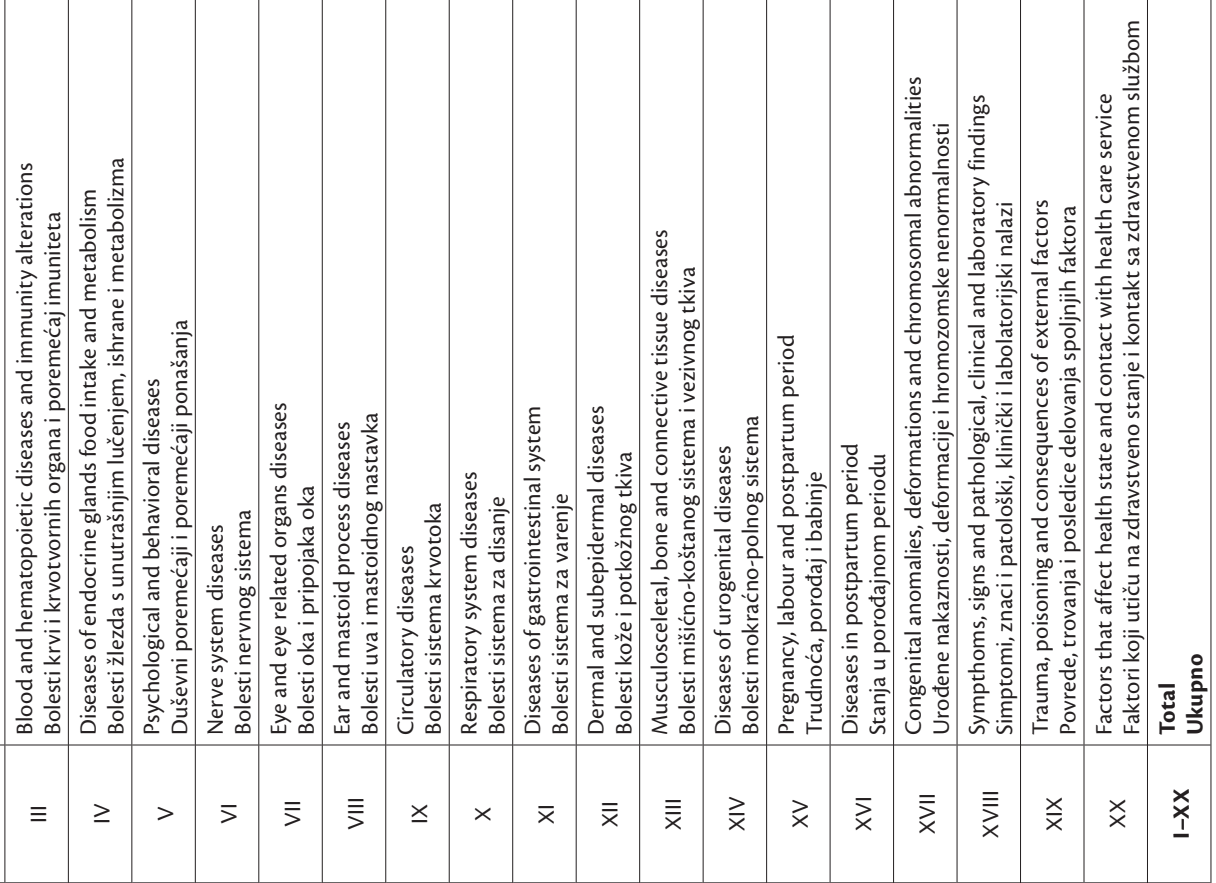




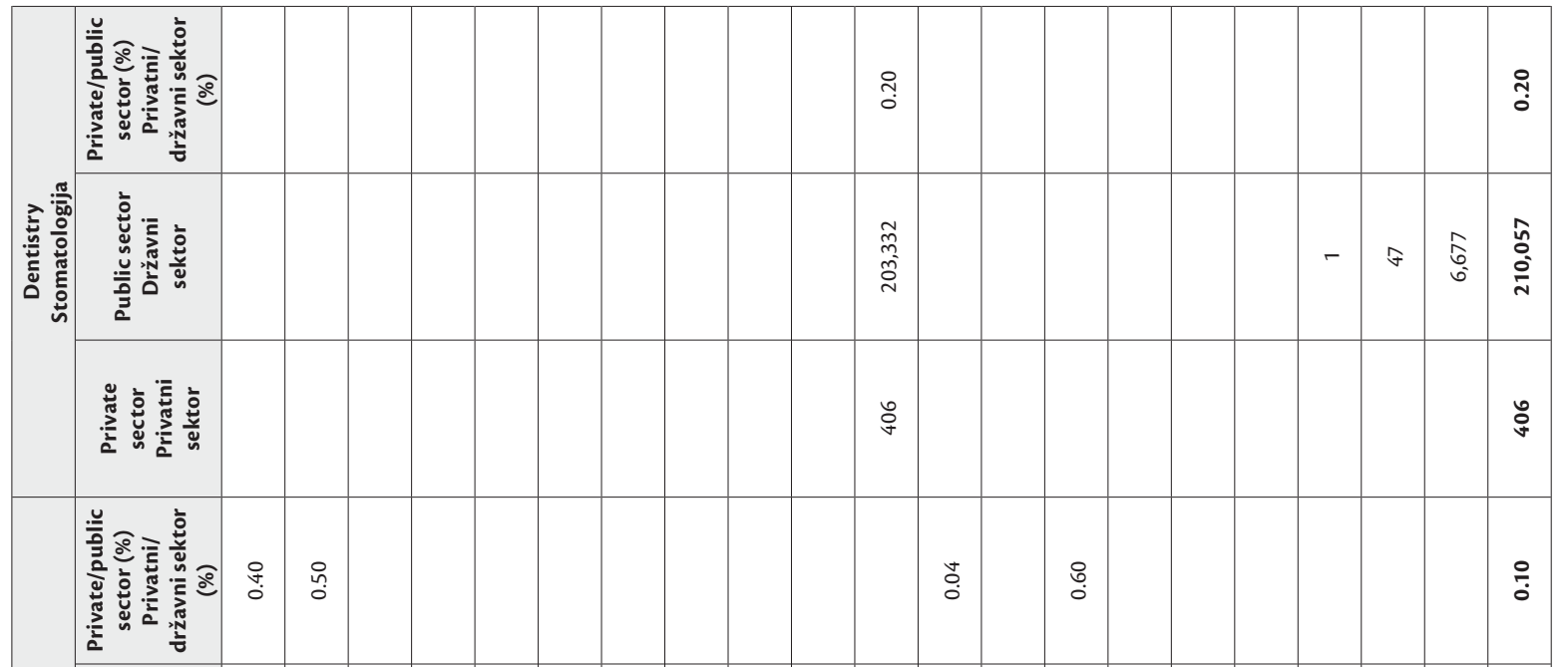

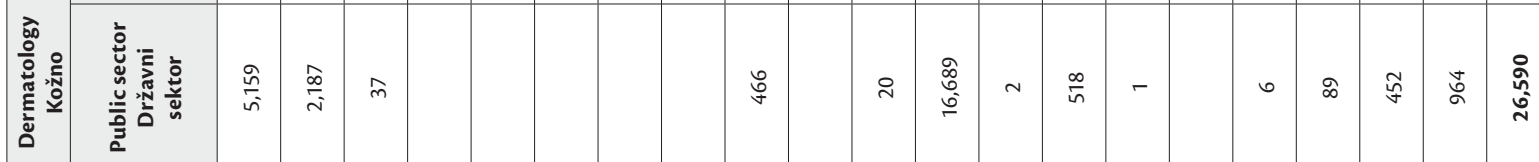

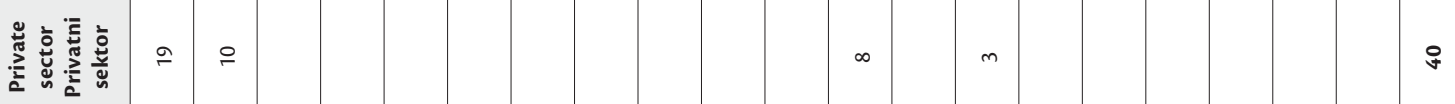

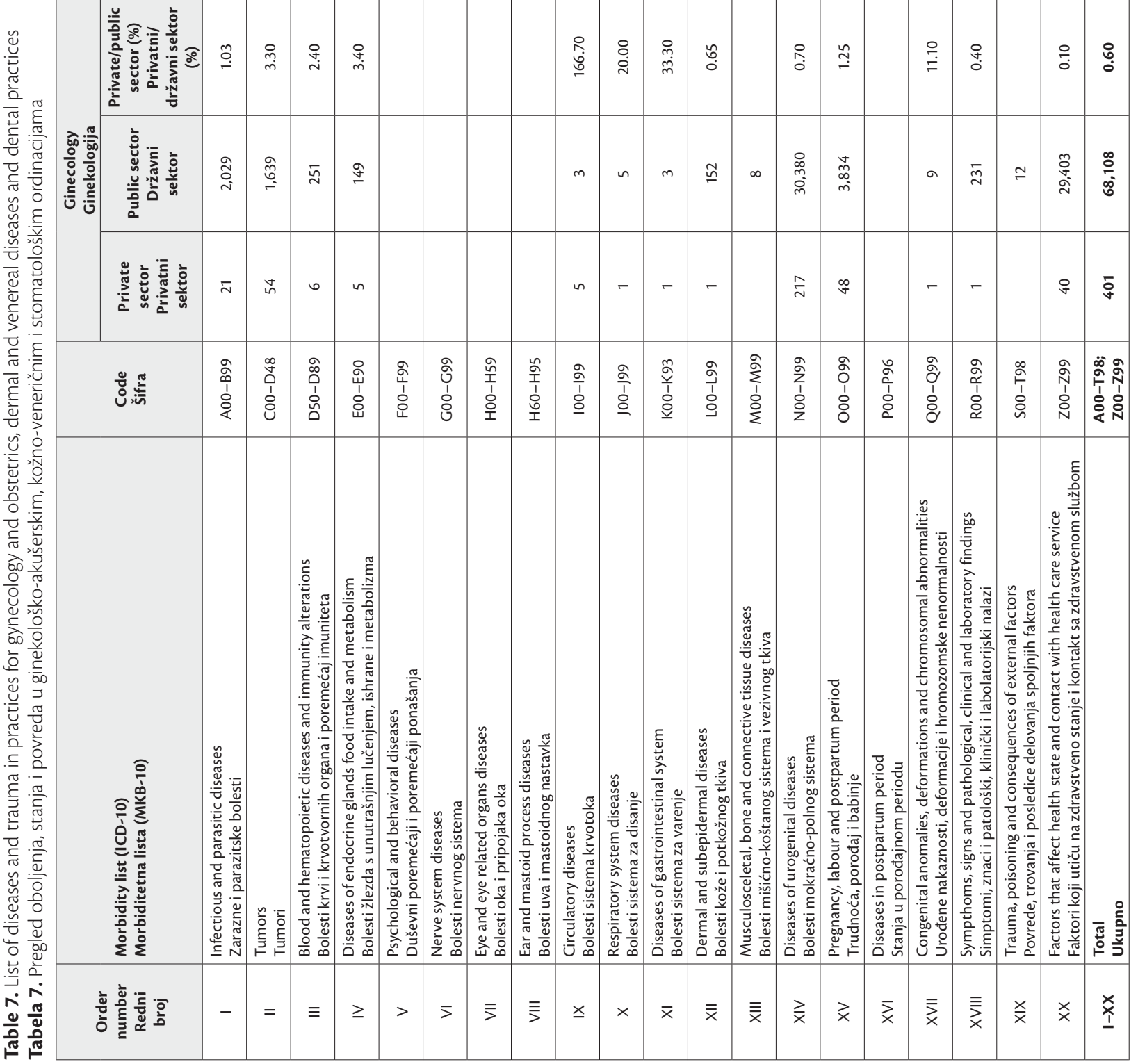


Table 8. Diseases and trauma in specialized practices

Tabela 8. Pregled oboljenja, stanja i povreda u specijalističkim ordinacijama

\begin{tabular}{|c|c|c|c|c|c|}
\hline \multirow{2}{*}{$\begin{array}{l}\text { Order } \\
\text { number } \\
\text { Redni } \\
\text { broj }\end{array}$} & \multirow[b]{2}{*}{$\begin{array}{l}\text { Morbidity list (ICD-10) } \\
\text { Morbiditetna lista (MKB-10) }\end{array}$} & \multirow[b]{2}{*}{$\begin{array}{l}\text { Code } \\
\text { Šifra }\end{array}$} & \multicolumn{3}{|c|}{$\begin{array}{l}\text { Specialized practices } \\
\text { Specijalističke ordinacije }\end{array}$} \\
\hline & & & $\begin{array}{l}\text { Private } \\
\text { sector } \\
\text { Privatni } \\
\text { sektor }\end{array}$ & $\begin{array}{l}\text { Public } \\
\text { sector } \\
\text { Državni } \\
\text { sektor }\end{array}$ & $\begin{array}{l}\text { Private/public } \\
\text { sector (\%) } \\
\text { Privatni/državni } \\
\text { sektor (\%) }\end{array}$ \\
\hline 1 & $\begin{array}{l}\text { Infectious and parasitic diseases } \\
\text { Zarazne i parazitske bolesti }\end{array}$ & A00-B99 & 54 & 4,580 & 1.20 \\
\hline II & $\begin{array}{l}\text { Tumors } \\
\text { Tumori }\end{array}$ & C00-D48 & 118 & 2,063 & 5.70 \\
\hline III & $\begin{array}{l}\text { Blood and hematopoietic diseases and immunity alterations } \\
\text { Bolesti krvi i krvotvornih organa i poremećaj imuniteta }\end{array}$ & D50-D89 & 29 & 744 & 3.90 \\
\hline IV & \begin{tabular}{|l} 
Diseases of endocrine glands food intake and metabolism \\
Bolesti žlezda s unutrašnjim lučenjem, ishrane i metabolizma
\end{tabular} & E00-E90 & 68 & 4,255 & 1.60 \\
\hline v & $\begin{array}{l}\text { Psychological and behavioral diseases } \\
\text { Duševni poremećaji i poremećaji ponašanja }\end{array}$ & F00-F99 & 48 & 5,120 & 0.90 \\
\hline $\mathrm{VI}$ & $\begin{array}{l}\text { Nerve system diseases } \\
\text { Bolesti nervnog sistema }\end{array}$ & G00-G99 & 51 & 701 & 7.20 \\
\hline VII & $\begin{array}{l}\text { Eye and eye related organs diseases } \\
\text { Bolesti oka i pripojaka oka }\end{array}$ & $\mathrm{H} 00-\mathrm{H} 59$ & 93 & 1,637 & 5.70 \\
\hline VIII & $\begin{array}{l}\text { Ear and mastoid process diseases } \\
\text { Bolesti uva i mastoidnog nastavka }\end{array}$ & $\mathrm{H} 60-\mathrm{H} 95$ & 17 & 1,680 & 1.01 \\
\hline IX & $\begin{array}{l}\text { Circulatory diseases } \\
\text { Bolesti sistema krvotoka }\end{array}$ & $100-199$ & 187 & 12,378 & 1.50 \\
\hline$x$ & $\begin{array}{l}\text { Respiratory system diseases } \\
\text { Bolesti sistema za disanje }\end{array}$ & J00-J99 & 142 & 15,532 & 0.90 \\
\hline$X I$ & $\begin{array}{l}\text { Diseases of gastrointestinal system } \\
\text { Bolesti sistema za varenje }\end{array}$ & K00-K93 & 123 & 5,901 & 2.00 \\
\hline XII & $\begin{array}{l}\text { Dermal and subepidermal diseases } \\
\text { Bolesti kože i potkožnog tkiva }\end{array}$ & L00-L99 & 33 & 3,329 & 1.00 \\
\hline XIII & $\begin{array}{l}\text { Musculosceletal, bone and connective tissue diseases } \\
\text { Bolesti mišićno-koštanog sistema i vezivnog tkiva }\end{array}$ & M00-M99 & 72 & 10,382 & 0.70 \\
\hline XIV & $\begin{array}{l}\text { Diseases of urogenital diseases } \\
\text { Bolesti mokraćno-polnog sistema }\end{array}$ & N00-N99 & 117 & 4,833 & 2.40 \\
\hline$x V$ & $\begin{array}{l}\text { Pregnancy, labour and postpartum period } \\
\text { Trudnoća, porođaj i babinje }\end{array}$ & O00-099 & 7 & 68 & 10.30 \\
\hline $\mathrm{xVI}$ & $\begin{array}{l}\text { Diseases in postpartum period } \\
\text { Stanja u porođajnom periodu }\end{array}$ & P00-P96 & 2 & - & - \\
\hline $\mathrm{XVII}$ & $\begin{array}{l}\text { Congenital anomalies, deformations and chromosomal abnormalities } \\
\text { Urođene nakaznosti, deformacije i hromozomske nenormalnosti }\end{array}$ & Q00-Q99 & 4 & 7 & 57.10 \\
\hline XVIII & $\begin{array}{l}\text { Sympthoms, signs and pathological, clinical and laboratory findings } \\
\text { Simptomi, znaci i patološki, klinički i labolatorijski nalazi }\end{array}$ & R00-R99 & 25 & 2,707 & 0.90 \\
\hline$X I X$ & $\begin{array}{l}\text { Trauma, poisoning and consequences of external factors } \\
\text { Povrede, trovanja i posledice delovanja spoljnjih faktora }\end{array}$ & S00-T98 & 25 & 5,278 & 0.50 \\
\hline$x x$ & $\begin{array}{l}\text { Factors that affect health state and contact with health care service } \\
\text { Faktori koji utiču na zdravstveno stanje i kontakt sa zdravstvenom službom }\end{array}$ & Z00-Z99 & 23 & 3,057 & 0.70 \\
\hline $1-X X$ & $\begin{array}{l}\text { Total } \\
\text { Ukupno }\end{array}$ & $\begin{array}{l}\text { A00-T98; } \\
\text { Z00-Z99 }\end{array}$ & 1,238 & 84,252 & 1.50 \\
\hline
\end{tabular}

On the list of morbidity by ICD-10, specialized clinics in private health sector were mostly visited by patients who suffered from circulatory system diseases (15\%) and diseases of respiratory system (12\%), while public health sector was mostly visited by those who suffered from diseases of respiratory $(18 \%)$ and circulatory system (15\%). The total number of patients in specialized clinics in private sector was 1,238 , while in public sector there were 84,252 patients.

For private sector in Belgrade, data was analyzed from 734 private health care facilities that provided their healthrelated statistical reports (Tables 9,10 and 11). It may be noted that public health sector had a far wider range of complex health institutions than private sector, mainly based on the number of clinics. Therefore, it can be concluded that public health sector was dominant in providing health services to the population.
Health care in private sector in 2009 was provided by a total of 1,051 staff, of which 579 were doctors $(55.1 \%)$, 94 employees with higher education (8.9\%) and 378 with secondary education (36\%). In public sector in Belgrade district, health care was provided by a total number of 31,404 employees, of which 6,084 were doctors, 655 pharmacists and 16,449 nurses and technicians.

According to the proposed methodology, the number of full time employees only were presented in tables, while the number of consultants was unknown and very variable. Therefore, it was difficult to adequately assess the average workload of doctors. The greatest number of staff was recorded in various specialty clinics, then in hospitals, women health care facilities and physical medicine.

In primary and specialized health care, according to the available data, a total number of 415,601 doctor visits were done, of which 284,503 were first visits, with an average of 
Table 9. Private health institutions in Belgrade

Tabela 9. Privatne zdravstvene ustanove u Beogradu

\begin{tabular}{|l|c|}
\hline $\begin{array}{l}\text { Public health institutions } \\
\text { Državne zdravstvene ustanove }\end{array}$ & $\begin{array}{c}\text { Number } \\
\text { Broj }\end{array}$ \\
\hline $\begin{array}{l}\text { Health center } \\
\text { Dom zdravlja }\end{array}$ & 3 \\
\hline $\begin{array}{l}\text { Hospital } \\
\text { Bolnica }\end{array}$ & 36 \\
\hline $\begin{array}{l}\text { Polyclinic } \\
\text { Poliklinika }\end{array}$ & 35 \\
\hline $\begin{array}{l}\text { Other specialized practices } \\
\text { Ordinacija različitih specijalnosti }\end{array}$ & 260 \\
\hline $\begin{array}{l}\text { Department } \\
\text { Zavod }\end{array}$ & 5 \\
\hline $\begin{array}{l}\text { Dental practices } \\
\text { Stomatološka ordinacija }\end{array}$ & 395 \\
\hline $\begin{array}{l}\text { Total } \\
\text { Ukupno }\end{array}$ & 734 \\
\hline
\end{tabular}

Source: The City Department for Public Health, Belgrade, 2010 Izvor: Gradski zavod za javno zdravlje, Beograd, 2010. godina

1.5 visits per disease treatment episode. In addition, 1.3 diagnoses were made. In public clinics $14,675,899$ visits were carried out.

There were 435 beds available in private hospitals. In 2009 , they achieved 21,767 hospital days, which is negligible in relation to the number of hospital days in public hospitals $(3,215,089)$.

As a part of this analysis, the comparison of morbidity pictures was performed both in private and public health sector by ICD-10 classification of diseases. The most common diagnosis in private health care system was related to circulatory system diseases $(65,391)$, diseases of urogenital system $(65,316)$, blood and immune disorders $(47,248)$, eye and eye related $(46,111)$ and respiratory system diseases $(33,709)$. A great number of systematic examinations carried out in specialized clinics $(29,135)$ was related to the fact that certain practices were contracted from sport associations and some private companies to complete these tests.

According to the available data, 5,023 patients were treated in hospitals with average length of treatment of 4.3 days.

Reports obtained from private dental practices suggested that usually one dentist was employed in the practice and had on average 379 patient visits per year. Total number of visits was 163,605 , of which 80,929 were first visits. Each episode of treatment on average included 2 visits and 1.5 final diagnoses. The most frequent diagnosis was caries $(72,362)$, followed by other teeth and periodontal diseases $(35,662)$. One dentist on average performed
Table 10. Public health institutions in Belgrade

Tabela 10. Državne zdravstvene ustanove u Beogradu

\begin{tabular}{|l|c|}
\hline $\begin{array}{l}\text { Public health institutions } \\
\text { Državne zdravstvene ustanove }\end{array}$ & $\begin{array}{c}\text { Number } \\
\text { Broj }\end{array}$ \\
\hline $\begin{array}{l}\text { Health center } \\
\text { Dom zdravlja }\end{array}$ & 16 \\
\hline $\begin{array}{l}\text { Clinic center } \\
\text { Klinički centar }\end{array}$ & 1 \\
\hline $\begin{array}{l}\text { Clinic-hospital center } \\
\text { Kliničko-bolnički centar }\end{array}$ & 4 \\
\hline $\begin{array}{l}\text { General hospital } \\
\text { Opšta bolnica }\end{array}$ & - \\
\hline $\begin{array}{l}\text { Special hospital } \\
\text { Specijalna bolnica }\end{array}$ & 7 \\
\hline $\begin{array}{l}\text { Clinic } \\
\text { Klinika }\end{array}$ & 2 \\
\hline $\begin{array}{l}\text { Department } \\
\text { Zavod }\end{array}$ & 11 \\
\hline $\begin{array}{l}\text { Institute } \\
\text { Institut }\end{array}$ & 11 \\
\hline $\begin{array}{l}\text { Institute/department for public health } \\
\text { Institut/zavod za javno zdravlje }\end{array}$ & 2 \\
\hline $\begin{array}{l}\text { Pharmacies } \\
\text { Apotekarska ustanova }\end{array}$ & 1 \\
\hline $\begin{array}{l}\text { Total } \\
\text { Ukupno }\end{array}$ & 55 \\
\hline
\end{tabular}

Source: Serbian Chamber of Health Institutions, 2010

Izvor: Komora zdravstvenih ustanova Srbije, 2010. godina

230 cavity preparations and fillings, extracted 39 teeth, performed 47 prosthetic and 7 orthodontic works.

The most common diagnosis in public health sector was related to circulatory system diseases, diseases of respiratory system, digestive system, musculoskeletal system and connective tissue, uro-genital system and diseases of endocrine glands, nutrition and metabolism.

The analysis of results obtained in Nisava and Toplica district is shown in Tables 12, 13 and 14. There were 207 medical clinics/institutions in private health sector in Nisava and Toplica district in 2009, out of which dental practices were the most frequent. Public health sector had a far wider range of complex health care institutions in Nisava and Toplica district, while private sector was mainly based on private practices. Therefore, public health sector was dominant in providing health care services to the population. The comparison of morbidity pictures in both private and public health sector by ICD-10 classification of diseases in Nisava and Toplica district was not able to perform as in South Backa and Belgrade district due to the lack of data.

The most common diagnoses in private health sector in the following areas were: dentistry (pulp and periapical tis-

Table 11. Number of employees in private and public sector in Belgrade district in 2009

Tabela 11. Broj zaposlenih u privatnom i državnom sektoru u Beogradskom okrugu 2009. godine

\begin{tabular}{|l|c|c|c|c|c|}
\hline $\begin{array}{l}\text { Sector } \\
\text { Sektor }\end{array}$ & $\begin{array}{c}\text { Total employees } \\
\text { Ukupno zaposlenih }\end{array}$ & $\begin{array}{c}\text { Doctors } \\
\text { Lekari }\end{array}$ & $\begin{array}{c}\text { Pharmacists } \\
\text { Farmaceuti }\end{array}$ & $\begin{array}{c}\text { Nurses and technicians } \\
\text { Sestre i tehničari }\end{array}$ & $\begin{array}{c}\text { Visits } \\
\text { Posete lekaru }\end{array}$ \\
\hline $\begin{array}{l}\text { Private } \\
\text { Privatni }\end{array}$ & 1,051 & 579 & - & 472 & 415,601 \\
\hline $\begin{array}{l}\text { Public } \\
\text { Državni }\end{array}$ & 31,404 & 6,084 & 655 & 16,449 & 21,767 \\
\hline
\end{tabular}

Source: The Institute for Public Health of Belgrade, 2010, and the Institute for Public Health of Serbia, 2010

Izvor: Zavod za javno zdravlje Grada Beograda, 2010, i Institut za javno zdravlje Srbije, 2010. 
Table 12. Private health institutions in Nisava and Toplica district in 2009

Tabela 12. Zdravstvene ustanove u privatnom sektoru u Nišavskom i Topličkom okrugu 2009. godine

\begin{tabular}{|l|c|}
\hline $\begin{array}{l}\text { Private health institutions } \\
\text { Privatne zdravstvene ustanove }\end{array}$ & $\begin{array}{c}\text { Number } \\
\text { Broj }\end{array}$ \\
\hline $\begin{array}{l}\text { General and specialized practice } \\
\text { Opšta i specijalistička ordinacija }\end{array}$ & 44 \\
\hline $\begin{array}{l}\text { Practise for gynecology and obstetrics } \\
\text { Ginekološko-akušerska ordinacija }\end{array}$ & 10 \\
\hline $\begin{array}{l}\text { Dental practice } \\
\text { Stomatološka ordinacija }\end{array}$ & 119 \\
\hline $\begin{array}{l}\text { Health center } \\
\text { Dom zdravlja }\end{array}$ & - \\
\hline $\begin{array}{l}\text { Polyclinic } \\
\text { Poliklinika }\end{array}$ & 6 \\
\hline $\begin{array}{l}\text { Medical office } \\
\text { Ambulanta }\end{array}$ & - \\
\hline $\begin{array}{l}\text { Hospital } \\
\text { Bolnica }\end{array}$ & 3 \\
\hline $\begin{array}{l}\text { Laboratory } \\
\text { Laboratorija }\end{array}$ & 7 \\
\hline $\begin{array}{l}\text { Laboratory for dental technics } \\
\text { Laboratorija za zubnu tehniku }\end{array}$ & 11 \\
\hline $\begin{array}{l}\text { Pharmacies } \\
\text { Apoteka }\end{array}$ & $\mathbf{2 0 7}$ \\
\hline $\begin{array}{l}\text { Department } \\
\text { Zavod }\end{array}$ & - \\
\hline $\begin{array}{l}\text { Rehabilitation center } \\
\text { Rehabilitacioni centar }\end{array}$ & - \\
\hline $\begin{array}{l}\text { Total } \\
\text { Ukupno }\end{array}$ & 7 \\
\hline Souce: Thelstite for Publc & \\
\hline
\end{tabular}

Source: The Institute for Public Health Nis, 2010 Izvor. Institut za javno zdravlje, Niš, 2010. godina

sue diseases), gynecology (tumors, uro-genital system diseases), rehabilitation (kinesiotherapy and physiotherapy), laboratory (blood and urine analysis and other analysis).

The most common diagnoses in public health care system were related to circulatory system diseases, diseases of respiratory system, musculoskeletal and connective tissue, diseases of uro-genital system and mental and behavioral disorders.

Health care in private sector in 2009 was provided by a total of 472 medical workers, including 292 doctors (62\%) and 180 workers with higher and a secondary school qualification (38\%), while in public sector health care was provided by 8,238 health care workers.

According to the proposed methodology, the tables included data about full time employees only, while the number of consultants was unknown and very variable. Therefore, it was difficult to adequately assess the average workload of doctors. The greatest number of staff was
Table 13. Public health institutions in Nisava and Toplica district in 2009

Tabela 13. Državne zdravstvene ustanove u Nišavskom i Topličkom okrugu 2009. godine

\begin{tabular}{|l|c|}
\hline $\begin{array}{l}\text { Private health institutions } \\
\text { Privatne zdravstvene ustanove }\end{array}$ & $\begin{array}{c}\text { Number } \\
\text { Broj }\end{array}$ \\
\hline $\begin{array}{l}\text { Health center } \\
\text { Dom zdravlja }\end{array}$ & 8 \\
\hline $\begin{array}{l}\text { Clinic center } \\
\text { Klinički centar }\end{array}$ & 2 \\
\hline $\begin{array}{l}\text { Health center } \\
\text { Zdravstveni centar }\end{array}$ & \\
\hline $\begin{array}{l}\text { General hospital } \\
\text { Opšta bolnica }\end{array}$ & 1 \\
\hline $\begin{array}{l}\text { Special hospital } \\
\text { Specijalna bolnica }\end{array}$ & 1 \\
\hline $\begin{array}{l}\text { Clinic } \\
\text { Klinika }\end{array}$ & 7 \\
\hline $\begin{array}{l}\text { Department } \\
\text { Zavod }\end{array}$ & 24 \\
\hline $\begin{array}{l}\text { Institute } \\
\text { Institut }\end{array}$ & 1 \\
\hline $\begin{array}{l}\text { Institute/department for public health } \\
\text { Institut/zavod za javno zdravlje }\end{array}$ & 2 \\
\hline $\begin{array}{l}\text { Pharmacies } \\
\text { Apotekarska ustanova }\end{array}$ & 1 \\
\hline $\begin{array}{l}\text { Total } \\
\text { Ukupno }\end{array}$ & 2 \\
\hline
\end{tabular}

Source: Serbian Chamber of Health Institutions, 2010

Izvor: Komora zdravstvenih ustanova Srbije, 2010. godina

recorded in various specialty clinics, then in hospitals, women health care and physical medicine practices.

According to the available data, a total number of 184,197 doctor visits were carried out in private sector and 3,895,852 in public sector due to various diseases.

Total number of 21,767 hospital days was achieved in private sector, which is negligible in relation to the number of hospital days in public hospitals in $2009(859,400)$.

\section{DISCUSSION}

Good and efficient health care system must integrate private and public institutions, hospitals, clinics and health centers, regardless of the proportion and relationship. In US, about $90 \%$ of health care services are provided by private sector, while in Europe this proportion is half-half, indicating that these two systems are evidently good to act as a whole and cooperate with each other for the benefit of patients [5]. In our country these two sectors are unnecessary conflicted. They experience each other as com-

Table 14. Number of employees in private and public health sector in Nisava and Toplica district in 2009

Tabela 14. Broj zaposlenih u privatnom i državnom sektoru u Nišavskom i Topličkom okrugu 2009. godine

\begin{tabular}{|l|c|c|c|c|c|c|}
\hline $\begin{array}{l}\text { Sector } \\
\text { Sektor }\end{array}$ & $\begin{array}{c}\text { Total employees } \\
\text { Ukupno zaposlenih }\end{array}$ & $\begin{array}{c}\text { Doctors } \\
\text { Lekari }\end{array}$ & $\begin{array}{c}\text { Pharmacists } \\
\text { Farmaceuti }\end{array}$ & $\begin{array}{c}\text { Nurses and technicians } \\
\text { Sestre i tehničari }\end{array}$ & $\begin{array}{c}\text { Visits } \\
\text { Posete lekaru }\end{array}$ & $\begin{array}{c}\text { Hospital days } \\
\text { Bolnički dani }\end{array}$ \\
\hline $\begin{array}{l}\text { Private } \\
\text { Privatni }\end{array}$ & 472 & 292 & - & 180 & 184,197 & 49,134 \\
\hline $\begin{array}{l}\text { Public } \\
\text { Državni }\end{array}$ & 8,238 & 1,733 & 117 & 3,795 & $3,895,852$ & 859,400 \\
\hline
\end{tabular}

Source: The Institute for Public Health Serbia, 2010, and the Institute for Public Health Nis, 2010 Izvor: Institut za javno zdravlje Srbije, 2010, i Institut za javno zdravlje Niš, 2010. godina 
petitors rather than partners. To provide more efficient health care in Serbia, this "rivalry” must be overcome by including both sectors in the integrated health care system.

Many countries have provided a chance for their private health care system to be a strong driver in the development of entire society. Swiss or German health care facilities have become world famous brands in which patients come from around the world. More and more countries are able to deliver health care services at highest standard, providing also financial benefit for their country. Recently, private health care has allowed strong economic boom in Singapore, India, Turkey, Malaysia, Greece, Brazil [6-11]. These destinations, among them some are far away, have become destinations where more and more patients from Serbia are heading to when having some health problems. Czech Republic is also tempting, and recently, Macedonia, Bulgaria and Romania have become important health care centers. Tukada, the famous hospital chain, has opened a hospital with 1,000 beds in Sofia, which has entered into the system of national health insurance, so every patient with the health care card can ask for help. With minimal additional payment in Romania, a patient has choice to have a treatment in private clinics. Many of our doctors, especially cardio surgeons and obstetricians who work in private hospitals in Macedonia shared their experience about successful cooperation of private and public sectors.

In Serbia, a patient who decides to use services offered by private institution has to pay the treatment twice: first through contributions allocated for public insurance, but later has to pay of the pocket for services in private sector. True personal choice of doctor would be free decision of someone to go to public or private health institutions for the same amount of money. Patients would really be able to make choices and have a feeling that they are really in hands of an expert they trust. Serbia cannot set up a health care system like most other countries, because in the past, private sector had a very negative connotation. Until before 15-20 years Serbian health care was absolute leader in former Yugoslavia. Now the situation has significantly changed. Doctors as well as patients are leaving Serbia, taking large outflow of money with them from the country. It would be quite better if we could become leaders in health care and acquire financial gain; instead of having our patients going for the treatment in Turkey, France, Czech Republic or Macedonia.

Some measures for equalization of both health sectors are needed in Serbia because it would provide a comprehensive and efficient health care. Not only declarative health sector reform is necessary, as it was the case in last eight years, but reform that would put the focus on patients as health care users who have all rights to choose the best health service for themselves.

\section{CONCLUSION}

On the basis of these results we concluded:

- The number of employees in private sector was far below the number of employees in public health sector;

- Private health care accounted far lower number of doctor visits, as well as number of hospital days as compared to public health sector;

- Morbidity picture was generally similar in both sectors;

- Public sector has remained the foundation of health care system in Serbia.

For the network of health institutions it can be concluded that private health sector was based mainly on large number of medical practices. Public sector had wider range of complex health care institutions and institutions based on high technology.

Considering the concentration of private sector, we can conclude that private practice was most developed in Belgrade, which was expected given the population density. Thus, more than one third of private health care service providers were in Belgrade. Private practices were least developed in southeastern part of Serbia. Health care providers such as medical and dental practices and pharmacies are the most common among private subjects.

\section{REFERENCES}

1. Zakon o javnim službama. Službeni glasnik RS, br. 42/91, 71/94, 79/2005.

2. Zakon o privatnim preduzetnicima. Službeni glasnik SRS, br. 54/89, 9/90. Službeni glasnik RS, br. 19/91,46/91, 31/93, 53/93, 67/93, 48/94, 53/95, 35/2002, 101/2005

3. Zakon o privrednim društvima. Službeni glasnik RS, br. 125/2004.

4. Zdravstveno-statistički godišnjak Srbije za 2009. godinu. Available from: http://www.batut.org.rs/index.php?content $=77$.

5. Knežević J. Dva sektora zdravstva razdvojena na štetu pacijenata. Magazin Biznis - Medicina i tržište. 2011.

6. http://www.medicalsingapore.com/

7. http://www.health-tourism-india.com/

8. http://www.medicaltourisminturkey.org/

9. http://www.malaysiahealthcare.com/

10. http://www.healthtourism.com.gr/

11. http://www.health-tourism.com/brazil-medical-tourism/

Received: 12/09/2011 • Accepted: 24/11/2011 


\title{
Komparativna analiza zdravstvenih ustanova, kadra i usluga privatnog i državnog sektora u zdravstvenom sistemu Srbije u 2009. godini
}

\author{
Milena Gajić-Stevanović1, Snežana Dimitrijević', Nevenka Teodorović2, Slavoljub Živković2 \\ 1'Institut za javno zdravlje Srbije „Dr Milan Jovanović Batut”, Beograd, Srbija; \\ 2Stomatološki fakultet, Univerzitet u Beogradu, Beograd, Srbija
}

\begin{abstract}
KRATAK SADRŽAJ
Uvod Prikupljanje podataka o strukturi i radu privatnog zdravstvenog sektora u Srbiji i njegovo uključivanje u planove funkcionisanja zdravstvene zaštite jedno je od važnih pitanja za donošenje odluka u zdravstvu, kako bi se dobila što preciznija slika o mogućnostima državnog i privatnog zdravstvenog sistema u Srbiji. Cilj ove komparativne analize bio je poređenje zdravstvenih ustanova, kadra, poseta lekaru, broja bolesničkih dana i morbiditeta prema Desetoj reviziji Međunarodne klasifikacije bolesti (MKB-10) u državnom i privatnom sektoru, u Južnobačkom, Nišavskom, Topličkom i Beogradskom okrugu u 2009. godini.

Materijal i metode rada Urađena je retrospektivna analitička komparativna studija na osnovu podataka o privatnim pružaocima zdravstvenih usluga dobijenim od Instituta za javno zdravlje u Novom Sadu, Instituta za javno zdravlje u Nišu i Gradskog zavoda za javno zdravlje u Beogradu. Podaci o kadru i morbiditetu u državnom sektoru zdravstvenog sistema Srbije za 2009. godinu preuzeti su od Centra za informatiku Instituta za javno zdravlje Srbije. Mreža državnih zdravstvenih ustanova u Južnobačkom, Nišavskom, Topličkom i Beogradskom okrugu u 2009. godini preuzeta je od Komore zdravstvenih ustanova Srbije.

Rezultati Analiza je pokazala da je zdravstvenu zaštitu u privatnom sektoru u 2009. godini u Beogradskom okrugu pružao ukupno 1.051 zaposlen medicinski radnik, dok su zdravstvenu zaštitu u državnom sektoru pružala 31.404 zaposlena lica. Utvrđeno je da državni zdravstveni sektor ima daleko širi spektar zdravstvenih ustanova od privatnog, koji se uglavnom temelji na velikom broju ordinacija. U Južnobačkom okrugu privatni sektor ima 323 ordinacije, u Beogradskom 655, a u Nišavskom i Topličkom 173. U državnom zdravstvenom sektoru u Južnobačkom okrugu ostvaruje se 17 puta veći broj poseta lekaru u odnosu na privatni (4.650.423 prema 267.356) i 111 puta veći broj bolesničkih dana (781.083 prema 7.023).

Zaključak Državni zdravstveni sektor je i dalje temelj zdravstvenog sistema Srbije. Privatni zdravstveni sektor se sve više razvija, ali njegova struktura i obim pruženih usluga i dalje su značajno manji u poređenju sa državnim.
\end{abstract}

Ključne reči: privatni zdravstveni sektor; zdravstvena zaštita; državni zdravstveni sektor u Srbiji

\section{UVOD}

Zakonom o zdravstvenoj zaštiti („Službeni glasnik RS” br. 107/05) je u članu 45. navedeno da zdravstvenu službu čine zdravstvene ustanove i privatna praksa, kao i zdravstveni radnici i saradnici koji zdravstvenu delatnost obavljaju u zdravstvenim ustanovama i u privatnoj praksi. Zdravstvene ustanove se mogu osnivati sredstvima u državnoj ili privatnoj svojini, a osnivači, pored različitih državnih organa, mogu biti i pravna i fizička lica. Privatnu praksu može osnovati nezaposleni zdravstveni radnik koji ima položen stručni ispit ili zdravstveni radnik u starosnoj penziji, ukoliko je dobio saglasnost komore zdravstvenih radnika. Za osnivanje i funkcionisanje zdravstvenih ustanova primenjuju se različiti propisi u privatnoj i u državnoj svojini. Zdravstvene ustanove u državnoj svojini osnivaju se u skladu s Planom mreže zdravstvenih ustanova, a osnivači su, u zavisnosti od vrste ustanove, Republika, autonomna pokrajina, grad ili opština. S obzirom na to da su one uspostavljene kao ustanove koje obavljaju delatnost od javnog značaja, njihovo osnivanje i organi upravljanja su definisani Zakonom o javnim službama [1]. S druge strane, privatni pružaoci zdravstvenih usluga u većini slučajeva posluju kao privatna praksa, odnosno osnivaju se i posluju u skladu sa Zakonom o privatnim preduzetnicima [2].

Postoji i određen broj preduzeća, uglavnom u formi društava s ograničenom odgovornošću, koji posluju u skladu s odredbama Zakona o privrednim društvima [3]. Precizan pregled broja preduzetnika i preduzeća koji pružaju zdravstvene usluge nije raspoloživ iz javnih izvora, jer Republički zavod za statistiku (RZS) u svojim saopštenjima u vezi sa statističkim registrima objavljuje zbirne podatke koji se odnose na delatnost „Zdrav- stvo i socijalni rad", a izdvajanje samo pružalaca usluga u zdravstvenoj zaštiti zahteva dodatnu dezagregaciju podataka. Kao i za sve ostale privredne subjekte, vode se dve statistike: jedna koja se odnosi na preduzeća, ustanove, zadruge i organizacije, i druga koja se odnosi na preduzetnike i zaposlene kod njih. Ovakav način prikupljanja podataka je često praćen neadekvatnim prikazom određenih statističkih pokazatelja.

Privatni pružaoci zdravstvenih usluga su ograničeni u pogledu poslova u oblasti zdravstva kojima mogu da se bave. Naime, postoji nekoliko aktivnosti navedenih u članovima 48. i 56. Zakona o zdravstvenoj zaštiti [4] koje mogu da se obavljaju isključivo u zdravstvenim ustanovama u državnoj svojini.

Struktura pružalaca usluga privatnog sektora u zdravstvu je raznolika, a distribucija zdravstvenih ustanova teritorijalno raspršena. Međutim, podaci o vrstama usluga koje pružaju privatne zdravstvene ustanove nedostaju i pored svih obligatornosti o vođenju evidencija i razmeni podataka pružalaca zdravstvenih usluga s nadležnim državnim službama i institutima koji su u obavezi da agregiraju sve podatke o sektoru zdravstva.

Cilj ove komparativne analize je upoređivanje zdravstvenih ustanova, kadra, broja poseta, broja bolesničkih dana i morbiditeta prema Desetoj reviziji Međunarodne klasifikacije bolesti (MKB-10) u državnom i privatnom sektoru u Južnobačkom, Nišavskom, Topličkom i Beogradskom okrugu u 2009. godini.

\section{MATERIJAL I METODE RADA}

Podaci o privatnim pružaocima zdravstvenih usluga dobijeni su od Instituta za javno zdravlje u Novom Sadu, Instituta za javno 
zdravlje u Nišu i Gradskog zavoda za javno zdravlje u Beogradu. Podaci o kadru i morbiditetu u državnom sektoru zdravstvenog sistema Srbije za 2009. godinu preuzeti su od Centra za informatiku Instituta za javno zdravlje Srbije. Mreža državnih zdravstvenih ustanova u Južnobačkom, Nišavskom, Topličkom i Beogradskom okrugu u 2009. preuzeta je od Komore zdravstvenih ustanova Srbije.

\section{REZULTATI}

Na osnovu raspoloživih podataka utvrđeno je da je u Republici Srbiji u 2009. godini bilo 5.519 privatnih ustanova (Tabela 1), a u mreži zdravstvenih ustanova državnog sektora 366 ustanova (Tabela 2).

Na osnovu tabele 3 može se uočiti da u privatnom zdravstvenom sektoru u Južnobačkom okrugu postoji ukupno 439 zdravstvenih ordinacija i ustanova. Najviše je stomatoloških ordinacija (222), ordinacija opšte i specijalističkih grana medicine (83) i apoteka (63).

Drugačija struktura i organizacija ustanova u državnom sektoru zdravstvene zaštite čini da je ukupan broj tih ustanova značajno manji od ustanova u privatnom sektoru (Tabela 4).

Južnobački okrug ima veoma jaku mrežu državnih zdravstvenih ustanova, uključujući i jedan klinički centar. Te ustanove pružaju zdravstvenu zaštitu celokupnom stanovništvu na svojoj teritoriji. Podaci o broju zaposlenih u tabeli 5 pokazuju da državni zdravstveni sektor u Južnobačkom okrugu ima sedam i po puta veći broj zaposlenih od privatnog, i to tri puta veći broj zaposlenih lekara i farmaceuta i oko osam puta veći broj osoblja s višom i srednjom stručnom spremom.

Kao posledica nerazvijenosti privatnog zdravstvenog sektora proizlazi činjenica da se u državnom zdravstvenom sektoru ostvaruje 17 puta veći broj poseta lekaru nego u privatnom (4.650.423 prema 267.356) i 111 puta veći broj bolesničkih dana (781.083 prema 7.023).

Procena stanja privatnog sektora u zdravstvu koju je marta 2009. godine uradio Institut za ekonomska i socijalna istraživanja potvrđuje da je privatni sektor i dalje slabo angažovan u pružanju zdravstvenih usluga stanovništvu. U okviru privatnog sektora stanovništvo najčešće koristi usluge stomatologa, dok usluge vanbolničkog lečenja u ordinacijama i ambulantama koristi svega 1,2\% stanovništva (u ukupnoj populaciji ima $27,2 \%$ korisnika). Lečenje u bolnicama koristi tek $0,1 \%$ stanovništva (u ukupnoj populaciji ima 6,1\% korisnika).

Podaci pokazuju da se stomatološke usluge podjednako koriste i u državnim i u privatnim ordinacijama, što je rezultat zakonskih izmena o korišćenju usluga, ali i načina funkcionisanja stomatoloških službi pri državnim domovima zdravlja.

Analiza morbiditetne slike u privatnom i državnom zdravstvenom sektoru prema MKB-10 klasifikaciji bolesti prikazana je u tabelama 6,7 i 8 .

Analiza ordinacija za zdravstvenu zaštitu dece školskog uzrasta pokazuje da privatni zdravstveni sektor najviše koriste oboleli od bolesti sistema za disanje (34\%), bolesti mokraćnopolnog sistema (10\%), zaraznih i parazitskih bolesti (9\%), dok državni zdravstveni sektor najviše koriste oboleli od bolesti sistema za disanje (45\%) i zaraznih i parazitskih bolesti (14\%). Godine 2009. se u ordinaciju za zdravstvenu zaštitu dece u pri- vatnom sektoru javio 91 pacijent, dok se u državnom javilo 197.713 pacijenata.

Posmatranjem morbiditetne liste MKB-10 u ginekološkoakušerskim ordinacijama uočava se da privatni zdravstveni sektor najviše koriste oboleli od bolesti mokraćno-polnog sistema (54\%) i tumora (13\%), dok državni zdravstveni sektor najviše koriste oboleli od bolesti mokraćno-polnog sistema (45\%) i od faktora koji utiču na zdravstveno stanje i kontakt sa zdravstvenom službom (43\%). U ginekološko-akušerskim ordinacijama u privatnom sektoru se 2009. godine lečio 401 pacijent, dok se u državnom sektoru lečilo 68.108 pacijenata.

U ordinacijama za kožno-venerične bolesti može se uočiti da privatni zdravstveni sektor koriste najviše oboleli od zaraznih i parazitskih bolesti $(47,5 \%)$ i tumora (25\%), dok državni zdravstveni sektor najviše koriste oboleli od bolesti kože i potkožnog tkiva (63\%) i zaraznih i parazitskih bolesti (19\%). Pacijenata koji su se javili ordinaciji za kožno-venerične bolesti u privatnom sektoru 2009. godine bilo je 40, a u državnom 26.590 .

Analiza stomatoloških ordinacija (morbiditet za odrasle) pokazala je da i privatni i državni zdravstveni sektor najviše koriste osobe obolele od bolesti sistema za varenje (100\% i 97\%). Stomatološkim ordinacijama (morbiditet za odrasle) u privatnom sektoru se 2009. godine javilo 406 pacijenata, a u državnom 210.057 pacijenata.

Posmatranjem morbiditetne liste MKB-10 specijalističkih ordinacija može se zapaziti da i privatni i državni zdravstveni sektor najviše koriste osobe obolele od bolesti sistema krvotoka (po 15\%) i bolesti sistema za disanje (12\% i 18\%). Specijalističkim ordinacijama u privatnom sektoru se 2009 . godine ukupno javilo 1.238 pacijenata, a u državnom 84.252 pacijenta.

U privatnom sektoru u Beogradu obrađeni su podaci iz 734 privatne zdravstvene ustanove koje su dostavile svoje zdravstveno-statističke izveštaje (Tabele 9,10 i 11). Uočava se da državni zdravstveni sektor ima daleko širi spektar kompleksnijih zdravstvenih ustanova od privatnog, koji se uglavnom temelji na velikom broju ordinacija. Stoga proizlazi da je državni zdravstveni sektor dominantan u pružanju zdravstvenih usluga stanovništvu.

Zdravstvenu zaštitu u privatnom sektoru u 2009. godini pružao je ukupno 1.051 zaposleni medicinski radnik: 579 lekara (55,1\%), 94 radnika s višom spremom (8,9\%) i 378 sa srednjom stručnom spremom (36\%). U državnom sektoru u Beogradskom okrugu zdravstvenu zaštitu pružala su ukupno 31.404 zaposlena lica: 6.084 lekara, 655 farmaceuta i 16.449 medicinskih sestara i tehničara.

Prema propisanoj metodologiji, u tabelama se prikazuju samo stalno zaposleni radnici, dok je broj konsultanata nepoznat i veoma promenljiv. Zbog toga je teško adekvatno sagledati prosečnu opterećenost lekara. Najviše kadrova registrovano je u različitim specijalističkim ordinacijama, zatim u stacionarnim ustanovama, zdravstvenoj zaštiti žena i fizikalnoj medicini.

U primarnoj i specijalističkoj delatnosti, prema raspoloživim podacima, zbog bolesti je u ordinacijama obavljena ukupno 415.601 poseta lekaru, od kojih je 284.503 prva, s prosečno jednom i po posetom po aktu lečenja i 1,3 postavljenih dijagnoza. U državnim ordinacijama ostvarena je 14.675 .899 poseta.

Privatne stacionarne ustanove imaju 435 postelja. U 2009. godini ostvarili su 21.767 bolesničkih dana, što je zanemarljivo u odnosu na ostvareni broj bolesničkih dana u državnim stacionarnim ustanovama (3.215.089). 
U okviru ove analize izvršena je i komparacija morbiditetne slike u privatnom i državnom zdravstvenom sektoru prema MKB-10 klasifikaciji bolesti. Najčešće postavljene dijagnoze u privatnom zdravstvenom sistemu odnosile su se na bolesti sistema krvotoka (65.391), oboljenja mokraćno-polnog sistema (65.316), bolesti krvi i poremećaja imuniteta (47.248), bolesti oka i pripoja oka (46.111) i bolesti sistema za disanje (33.709). Veliki broj sistematskih pregleda u specijalističkoj delatnosti (29.135) uslovljen je time što su određene ordinacije sklopile ugovore za obavljanje ovih pregleda sa sportskim društvima i nekim privatnim firmama.

U stacionarnim ustanovama su, prema dostavljenim podacima, lečena 5.023 bolesnika, a prosečna dužina lečenja iznosila je 4,3 dana.

Iz izveštaja privatnih stomatologa uočava se da u ordinaciji najčešće radi samo jedan stomatolog, koji godišnje u proseku ima 379 poseta. Ukupno je bilo 163.605 poseta, od čega 80.929 prvih. Svaki akt lečenja u proseku je ostvaren kroz dve posete i jednom i po konačnom dijagnozom. Najčešće je postavljena dijagnoza karijesa (72.362), a zatim slede druge bolesti zuba i potpornih struktura (35.662). Jedan stomatolog je u proseku godišnje plombirao 230 zuba, izvadio 39 zuba i obavio 47 protetičkih i sedam ortodontskih radova.

Najčešće postavljene dijagnoze u državnom zdravstvenom sistemu odnosile su se na bolesti sistema krvotoka, sistema za disanje, za varenje, mišićno-koštanog sistema i vezivnog tkiva, mokraćno-polnog sistema, bolesti žlezda s unutrašnjim lučenjem, ishrane i metabolizma.

Analiza dobijenih rezultata u Niškom i Topličkom okrugu prikazana je u tabelama 12, 13 i 14. Godine 2009. u privatnom zdravstvenom sektoru Nišavskog i Topličkog okrugu postojala je 207 zdravstvena ustanova, odnosno ordinacija, od čega najviše stomatoloških. Državni zdravstveni sektor u ovom okrugu ima daleko širi spektar složenijih zdravstvenih ustanova, dok se privatni uglavnom temelji na velikom broju ordinacija. Stoga proizlazi da je državni zdravstveni sektor dominantan u pružanju zdravstvenih usluga stanovništvu.

Poređenje morbiditetne slike u privatnom i državnom zdravstvenom sektoru prema MKB-10 klasifikaciji bolesti u Nišavskom i Topličkom okrugu nije se moglo obaviti kao u Južnobačkom i Beogradskom zbog nedostataka podataka.

Oblasti u okviru kojih su bile postavljene najčešće dijagnoze u privatnom zdravstvenom sistemu su: stomatologija (bolesti pulpe i parapikalnog tkiva), ginekologija (tumori, bolesti mokraćno-polnog sistema), rehabilitacija (kineziterapija i fizioterapija), laboratorija (analiza krvi, urina i razne vrste laboratorijskih analiza). Najčešće postavljene dijagnoze u državnom zdravstvenom sistemu odnosile su se na bolesti sistema krvotoka, sistema za disanje, mišićno-koštanog sistema i vezivnog tkiva, mokraćno-polnog sistema, duševne i poremećaje ponašanja.

Zdravstvenu zaštitu u privatnom sektoru u 2009. godini pruŽala su ukupno 472 zaposlena medicinska radnika: 292 lekara (62\%) i 180 radnika s višom i srednjom stručnom spremom (38\%), dok je u državnom sektoru zdravstvenu zaštitu pružalo 8.238 medicinskih radnika.

Prema propisanoj metodologiji, u tabelama se prikazuju samo stalno zaposleni radnici, dok je broj konsultanata nepoznat i veoma promenljiv. Zbog toga je teško adekvatno sagledati prosečnu opterećenost lekara. Najviše kadrova registrovano je u različitim specijalističkim ordinacijama, zatim u stacionarnim ustanovama, te u zdravstvenoj zaštiti žena i fizikalnoj medicini.

Zbog bolesti u ordinacijama je, prema raspoloživim podacima, obavljeno ukupno 184.197 poseta privatnom lekaru, dok su u državnom sektoru ostvarene 3.895.852 posete.

U 2009. godini evidentirana su 49.134 bolesnička dana, što je zanemarljivo u odnosu na ostvareni broj bolničkih dana u državnim stacionarnim ustanovama (859.400).

\section{DISKUSIJA}

Dobar i efikasan zdravstveni sistem obavezno integriše usluge i privatnih i državnih ustanova, bolnica, klinika i domova zdravlja, bez obzira u kojoj su proporciji i međusobnom odnosu. U Sjedinjenim Američkim Državama oko 90\% medicinskih usluga pruža privatni sektor, dok je u Evropi ta srazmera polapola, što ukazuje na to da su ova dva sistema evidentno dobra, da deluju kao celina i rade jedni za druge u korist pacijenata [5]. U našoj zemlji ova dva sektora su nepotrebno sukobljena. Odnos između njih je konkurentski, a ne partnerski. Jedina mogućnost za efikasniju zdravstvenu zaštitu u Srbiji jeste da se taj „rivalitet” prevaziđe uključivanjem oba sektora u integrisanu zdravstvenu zaštitu.

Mnoge zemlje pružile su mogućnost privatnom zdravstvu da bude snažan pokretač u razvoju celokupnog društva. Zdravstvene ustanove u Švajcarskoj i Nemačkoj postale su svetski čuveni brendovi u koje dolaze bolesnici iz celog sveta. Sve je više zemalja koje su u stanju da pruže usluge najvišeg nivoa, što se odražava i na interes i finansijsku korist cele države. U poslednje vreme privatno zdravstvo omogućilo je snažan ekonomski bum Singapuru, Indiji, Turskoj, Maleziji, Grčkoj i Brazilu [6-11]. Ove destinacije, među kojima su i veoma daleke, postaju odredišta na koja sve češće odlaze bolesnici iz Srbije. Takođe je primamljiva Češka, a u poslednje vreme i Makedonija, Bugarska i Rumunija. Tukada, čuveni lanac bolnica, otvorio je u Sofiji punkt sa 1.000 kreveta koji je ušao u sistem državnog zdravstvenog osiguranja, tako da svaki pacijent sa zdravstvenom knjižicom može da im se obrati za pomoć. I u Rumuniji pacijent uz minimalnu doplatu ima mogućnost izbora lečenja u privatnim klinikama. Mnogo je naših lekara, naročito kardiohirurga i akušera, koji rade u privatnim bolnicama u Makedoniji i čija iskustva govore da je tamo veoma uspešno usklađeno finansiranje oba sektora.

U Srbiji pacijent koji se opredeli za usluge privatnih ustanova svoje lečenje plaća dvostruko: najpre kroz doprinose koje izdvaja za državno osiguranje, a posle plaća iz džepa i za usluge kod privatnika. Pravi lični izbor lekara bilo bi tek slobodno opredeljenje ljudi da se leče u državnoj ili privatnoj zdravstvenoj ustanovi za istu cenu. Pacijent bi mogao da bira, a imao bi i osećaj da je zaista došao u ruke stručnjaka u kojeg ima poverenja. Srbija, nažalost, ne može da ustroji zdravstveni sistem poput većine drugih zemalja, jer je u prošlosti privatni sektor nosio veoma negativnu konotaciju. Do pre 15-20 godina zdravstvo Srbije bilo je apsolutni lider na prostoru bivše Jugoslavije. Sada je situacija bitno izmenjena. Posledica je uočljiv odlazak i lekara i pacijenata u druge zemlje, a s njima i veliki odliv novca. Umesto da se postaramo da sa svojim kapacitetima i kadrom u privatnom i državnom sektoru postanemo centar lečenja i sti- 
canja materijalne dobiti, naši pacijenti sve češće odlaze na lečenje u Tursku, Francusku, Češku i Makedoniju.

U Srbiji bi trebalo da se preduzmu mere za izjednačavanje oba sektora zdravstva, koja bi omogućila sveobuhvatnu efikasnu zdravstvenu zaštitu. Nužna je ne samo deklarativna reforma zdravstvenog sektora, kao što je to slučaj poslednjih osam godina, već reforma koja u fokus stavlja pacijenta kao korisnika zdravstvene zaštite, koji ima sva prava da izabere najbolje za sebe.

\section{ZAKLJUČAK}

Na osnovu dobijenih rezultata može se zaključiti sledeće:

- Broj zaposlenih u privatnom zdravstvenom sektoru je mnogo manji od broja zaposlenih u državnom sektoru;

- Privatni zdravstveni sektor ostvaruje znatno manji broj poseta lekaru i broj bolničkih dana u odnosu na državni sektor;
- Morbiditetna slika je uglavnom slična u oba sektora;

- Državni zdravstveni sektor je i dalje temelj zdravstvenog sistema Srbije.

Kada je u pitanju mreža zdravstvenih ustanova, uočava se da se privatni zdravstveni sektor temelji uglavnom na velikom broju zdravstvenih ordinacija u kojima pruža zdravstvenu zaštitu stanovništvu. Državni sektor ima širi spektar složenijih zdravstvenih ustanova i zasniva se na ustanovama visoke tehnologije.

Posmatrajući koncentraciju privatnog sektora, uočava se da je privatna praksa u pružanju zdravstvenih usluga najrazvijenija u Beogradu, što je i očekivano, s obzirom na gustinu populacije. Dakle, više od trećine privatnih pružalaca usluga u zdravstvu nalazi se u Beogradu. Privatne usluge su najslabije razvijene u jugoistočnoj Srbiji. Među pružaocima zdravstvenih usluga najčešće su lekarske i stomatološke ordinacije i apoteke u privatnom sektoru. 